\title{
Growth characteristics, phytochemicals and mineral composition of Ocimum gratissimum applied with Albit $^{\circledR}$ bioproduct
}

\author{
S.T. Anjorin ${ }^{1}$ and N.H. Ugwu ${ }^{2}$ \\ ${ }^{1}$ Department of Crop Science, Faculty of Agriculture, University of Abuja, Abuja, Nigeria \\ ${ }^{2}$ Department of Biological Sciences, University of Abuja, Abuja, Nigeria
}

\begin{abstract}
Ocimum gratissimum (basil) was seed-dressed and foliar sprayed with Albit $\circledast$ bioregulator/biopesticide and assessed for its growth characteristics, phytochemicals and mineral composition. Those applied with Albit ${ }^{\circledR}$ had increased number of leaves (two/ plant), increased shoot height $(2 \mathrm{~cm} /$ plant $)$ at 28 days after sowing (DAS), increased shoot weight $(7.4 \mathrm{~g} / \mathrm{plant})$ and roots weight $(3 \mathrm{~g} / \mathrm{plant})$ at 182 DAS than the control without Albit ${ }^{\circledR}$ application. Albit ${ }^{\circledR}$ application induced flowering 15 days earlier than those in the control plots. Steroid phytochemical were present in the leaves and roots of basil applied with $\mathrm{Albit}^{\circledR}$ while alkaloid was absent in basil leaves applied with the biosubstance. The potassium, magnesium, zinc and calcium contents in the basil leaves applied with Albit $\circledast$ were significantly higher $(P \leq 0.05)$ than from the basil in the control. Albit ${ }^{\circledR}$ has proven to be a promising alternative input for producing lamiaceous culinary plants with enhanced growth characteristics and mineral composition.
\end{abstract}

Keywords: Albit $^{\circledR}$ biosubstance, Growth characteristics, Minerals, Phytochemicals, Ocimum gratissimum

\section{INTRODUCTION}

Ocimum gratissimum L. (Family Lamiaceae) commonly called basil, is a culinary herb with pungent sweet smell. Propagation of basil is through seeds and also reliably from cuttings. (Calixto, 2000; Ehiagbonare, 2004). The foliage is commonly used fresh in cooked recipes or added at the last moment, as cooking quickly destroys the flavour (Giami et al., 2005). Studies have established that compounds in basil oil have potent antioxidant, anticancer, antiviral and antimicrobial properties (Essawi and Srour, 2000; Rabelo et al., 2003 Adebolu and Salau, 2005). Basil has also been used from time immemorial both prophylactically and curatively (Gills, 1992; Chen et al., 1994; George, 1994 and El-said et al., 2001).

Albit $^{\circledR}$ - a plant growth regulator and biofungicide is reported to have improved germinability and seedling vigour, improve vegetative growth, accelerates maturity and yield of cereals and vegetables (Albit Biotechnology LLC, 2008). Albit $\AA$ TPS is composed of hydrolysate of microorganisms (Bacillus megaterium $H$ Pseudomonas aurefaciens); microelements, growth substances (poly-betahydroxybutyrate $\left(6.2 \mathrm{~g}\right.$ PHB $\left.\mathrm{L}^{-1}\right)$ and terpenes, extracted from plant shoots (Zlotnikov, 2006). Albit ${ }^{\circledR}$ is formulated as an alternative farm input to synthetic fertilizer and fungicide which are less environment- friendly. There is a dearth of information on the performance of Lamiaceous crops applied with Albit ${ }^{\circledR}$. This study was carried out to assess the effect of Albit $\circledast$ seed dressing and foliar spraying on the germination, growth characteristics, biomass, phytochemicals and mineral composition of the shoot and root of $O$. gratissimum.

\section{MATERIALS AND METHODS}

Loamy soil was collected from the Biological Science Experimental garden, University of Abuja, Abuja. Each of the $30 \mathrm{~cm}$-diameter polythene pots was filled with two kilograms $(2 \mathrm{~kg})$ of the soil.

Collection of seeds, Albit $^{\circledR}$ and sowing of treated seeds: $O$. gratissimum seeds were collected from farmers in Kwali, Abuja. The matured brown fruits were splitted to bring out the small dried black seeds. Seeds were pre-soaked for $4 \mathrm{~h}$ in $\mathrm{Albit}^{\circledR}$ at concentration of $2 \mathrm{ml} / \mathrm{L}$ distilled water in a $9 \mathrm{~cm}$ diameter Petri-dish. The seeds for the control were not pre-soaked with the $A l b i t^{\circledR}$. After the solution was drained off, 10 seeds per polypots were sown at $2 \mathrm{~cm}$ depth. The seeds treated with Albit $^{\circledR}$ were sown in a total of 24 polypots and the control was sown in 24 polypots. Watering was done every other day and weeding was also done when necessary. First foliar sprayings of the seedlings was carried out at 4-5 leaf stage ( 3 weeks after sowing-WAS) and the second at 
10-12 leaf stage (7 WAS) each at the rate $2 \mathrm{~mL}$ Albit $₫ L^{1}$ water evenly sprayed with a hand sprayer.

Growth parameters measured: The number of leaves per plant was counted at 28 and 38 DAS respectively. Also the shoot length was obtained at the same periods. Leaf area was obtained by using graph paper. Dry weight of the stem, root and leaf were obtained by the use of electronic balance ( $\mathrm{Hx}$ 6000, MAX 6100g).

Phytochemical analysis: The phytochemical screening of the ethanolic leaf extract took place in Natural product chemistry laboratory of Sheda Science and Technology Complex (SHESTCO) Sheda-Abuja. The roots, shoots and leaves of the basil were dried in the oven at $70^{\circ} \mathrm{C}$ for $24 \mathrm{~h}$ before being grounded into powder with a $240 \mathrm{v}$ Warring blender (3 M 821 Thomas scientific, Swedesborn, U.K). One gram $(1 \mathrm{~g})$ each of the respective leaf powder was soaked in $100 \mathrm{ml}$ of ethanol for $48 \mathrm{~h}$. They were later filtered with cheese cloth and the liquid filterate concentrated with rotary vacuum evaporator. The extracts were analysed for the presence of glycosides, flavonoid, tannins, terpenoids, alkaioid, steroids, balsam and saponin derivatives in line with the procedures described by Sofowora (1993).

\section{Determination of mineral composition}

Preparation of samples: The dried basil leaves, stems and roots were separately pulverized to fine powder using the Warring blender. One gram $(1 \mathrm{~g})$ of each samples were digested with nitric acid $\left(\mathrm{HNO}_{3}\right)$, filtered and make to $100 \mathrm{ml}$ mark in a volumetric flask. The resulting solution was concentrated in rotary vacuum evaporator (RE 300B, Bar Loworld Scientific Ltd OSA, U. K).

Reagents and Apparatus: All the reagents and chemicals used were of analytical grade obtained from BDH and syma-Aldrich. The standards used were prepared in the laboratory, Chemistry Advanced Laboratory (CAL, SHESTCO), Sheda, Abuja. Distilled water and acid washed glass wares were used throughout the analysis.
Wet digestion method: One $(1 \mathrm{~g})$ of each of the samples was weighed into separate beakers and treated with $10 \mathrm{ml}$ of concentrated $\mathrm{HNO}_{3}$, heated to reflux on an electric hot plate at $90{ }^{\circ} \mathrm{C}$ until digestion is complete. Side by side $10 \mathrm{ml}$ of nitric acid was also added to empty beakers which served as blank. The content of the beaker was allowed to cool, filtered through Whatman No. 42 filter paper into volumetric flasks and make up to volume of $100 \mathrm{ml}$ with distilled water. The flasks were then covered.

Determination of minerals: The mineral contents of basil were determined in six samples namely; the leaf with $\mathrm{Albit}^{\circledR}$, leaf without Albit ${ }^{\circledR}$, stem with Albit ${ }^{\circledR}$, stem without $A$ lbit ${ }^{\circledR}$, root with Albit $^{\circledR}$ and root without Albit $^{\circledR}$. Working standard solutions of Magnesium $(\mathrm{Mg})$, Zinc ( $\mathrm{Zn})$, Calcium (Ca), Iron (Fe), Manganese $(\mathrm{Mn})$, Potassium $(\mathrm{K})$, Phosphorous $(\mathrm{P})$ were prepared from stock standard solution (1000ppm) and absorbance were noted for standard solutions of each elements and samples using Atomic Absorption Spectrometer (AAS) 969 UNICAM (Sahito et al., 2002). While (K) was analysed using flame photometer. A blank reading was also taken and necessary correction was made during the calculation of concentration of various elements.

Data collected were subjected to Analysis of Variance (ANOVA) and differences among the mineral components of the plant parts were determined with Duncan Multiple Range Test (DMRT) at 0.05 level of probability, using SAS 9.0 (2002) statistical package. $P$ values $\leq 0.05$ were considered statistically significant.

\section{RESULTS}

Growth characteristics of $O$. gratissimum applied with Albit $\circledast$ and without Albit ${ }^{\circledR}$ : As a result of seed treatment and foliar spraying with $A \mathrm{Albit}^{\circledR}$, the number of leaves, shoot height, leaf area, number of flower, shoot and root weights were higher than the ones without Albit ${ }^{\circledR}$ (Table 1).

Table1: Growth characteristics of O. gratissimum applied with Albit@ and without $\quad$ Albit $^{\circledR}$

\begin{tabular}{|c|c|c|c|c|c|c|c|c|c|}
\hline Treatment & $\begin{array}{l}\text { No. of } \\
\text { leaves } \\
\text { at } 28 \\
\text { DAS }\end{array}$ & $\begin{array}{l}\text { Shoot- } \\
\text { height } \\
\text { (cm) } 28 \\
\text { DAS }\end{array}$ & $\begin{array}{l}\text { No. of } \\
\text { leaves } \\
38 \text { DAS }\end{array}$ & $\begin{array}{l}\text { Shoot- } \\
\text { height } \\
38 \text { DAS }\end{array}$ & $\begin{array}{l}\text { Leaf- } \\
\text { Area } \\
\left(\mathrm{cm}^{2}\right) \\
\text { at } 42 \\
\text { DAS }\end{array}$ & $\begin{array}{l}\text { Days to } \\
50 \% \\
\text { flowering } \\
\text { (DAS) }\end{array}$ & $\begin{array}{l}\begin{array}{l}\text { No. of } \\
\text { flowers }\end{array} \\
\text { (182 } \\
\text { DAS) }\end{array}$ & $\begin{array}{l}\text { Shoot } \\
\text { weight(g) } \\
\text { (DAS) }\end{array}$ & $\begin{array}{l}\text { Root } \\
\text { weight } \\
\text { (g) } \\
\text { (DAS) }\end{array}$ \\
\hline With Albit® & 8 & 5 & 12 & 16 & 85 & 148 & 11 & 23.6 & 7 \\
\hline Control(noAlbit) & 6 & 3 & 10 & 13 & 54 & 163 & 3 & 16.2 & 4 \\
\hline
\end{tabular}

DAS = Days After Sowing. Data is mean of three replicates 
At 28 DAS, the mean value of the leaves of basil applied with Albit $\circledast$ had two leaves more than that of the control and shoot height applied with Albit $\circledast$ was 2 $\mathrm{cm}$ higher than the ones with no Albit ${ }^{\circledR}$ application. At 38 DAS (i.e. 10 days interval), the mean values of the leaves of basil applied with $\mathrm{Albit}^{\circledR}$ had two leaves more than that of the control and shoot height applied with Albit $^{\circledR}$ was $3 \mathrm{~cm}$ higher than the control. At 42 DAS, the mean leaf area of basil applied with Albit ${ }^{\circledR}$ was $31 \mathrm{~cm}^{3}$ more than that of the control. The mean days of basil without $\mathrm{Albit}^{\circledR}$ to flower was 15 days more than that with Albit $₫$. The number of flower on basil applied with $\mathrm{Albit}^{\circledR}$ was eight (8) more than those with $\mathrm{Albit}^{\circledR}$ application at 182 DAS. Shoot weight of basil with Albit $^{\circledR}$ at 182 DAS was $7.4 \mathrm{~g}$ heavier than the control. The mean root biomass of basil applied with $\mathrm{Albit}^{\circledR}$ at the same time was $3 \mathrm{~g}$ more than those in the control plots.

Saponin was present in leaves and stems of basil applied with or without Albit $\circledast$ but was absent in their roots (Table 2). Flavonoid was present only in the leaves of basil, applied with and without Albit $\AA$ but was absent in their stems and roots. Tannin and balsam were present in all the leaves, stems and roots applied with or without Albit ${ }^{\circledR}$. Glycosides was absent in the leaves of basil applied with and without Albit $^{\circledR}$ and was present in the stems and roots applied with and without Albit ${ }^{\circledR}$. Terpenoid was absent in all the leaves, stems and roots applied with and without Albit $^{\circledR}$. Steroid was present in the leaves and roots with Albit $^{\circledR}$ and absent in those without the Albit $^{\circledR}$. However alkaloid was in the leaves applied with Albit $^{\circledR}$ and present in those without Albit $^{\circledR}$. Albit ${ }^{\circledR}$ application did not alter the composition of phytochemicals in the stem of basil. Tannins and balsam were present in all the basil parts applied with and without $\mathrm{Albit}^{\circledR}$ while terpenoid was absence in all the parts.

Minerals content in 0 . gratissimum parts: Table 3 shows the results of mineral contents in the parts of basil applied with and without Albit ${ }^{\circledR}$ biosubstance.

Table 3 shows that the highest $\mathrm{K}$ content $(3.289 \mathrm{mg}$ $\left.\mathrm{g}^{-}{ }^{1}\right)$ was found in the leaves of basil applied with Albit ${ }^{\circledR}$ and was not significantly different $(P>0.05)$ from the $\mathrm{K}$ content in basil root without Albit ${ }^{\circledR}$. The $\mathrm{K}$ content in the root from basil applied with $\mathrm{Albit}^{\circledR}$ was significantly lower $(P \leq 0.05)$ than all other treatment. The $\mathrm{Mg}$ content in basil stem with no Albit $^{\circledR}$ application was significantly higher $(P \leq 0.05)$ than every other treatment. There was no significant difference $(P>0.05)$ between the Mg content in basil leaf applied with $\mathrm{Albit}^{\circledR}$ and basil root applied with Albit $^{\circledR}$. However, the $\mathrm{Mg}$ content in the basil root without $A l b i{ }^{\circledR}{ }^{\circledR}$ was significantly lower $(P \leq 0.05)$ than any other treatments.

The $\mathrm{Zn}$ content in basil leaf with $\mathrm{Albit}^{\circledR}$ was significantly higher $(P \leq 0.05)$ than any other treatment. There was no significant difference $(P>0.05)$ between the $Z n$ content in basil leaf without Albit ${ }^{\circledR}$ and basil root with Albit $^{\circledR}$. The $\mathrm{Zn}$ content in the basil stem with Albit $^{\circledR}$ was significantly lower $(P \leq 0.05)$ than any other treatments. The highest $\mathrm{Ca}$ content $\left(31.175 \mathrm{mg} \mathrm{g}^{-1}\right)$ was found in basil leaf with Albit ${ }^{\circledR}$ and was significantly higher $(P \leq 0.05)$ than any other treatments. There was no significant difference $(P>0.05)$ between the Ca content in basil stem with Albit and basil stem without Albit ${ }^{\circledR}$.

Table 2: Phytochemicals in O. gratissimum applied with Albit ${ }^{\circledR}$ and without Albit ${ }^{\circledR}$

\begin{tabular}{|c|c|c|c|c|c|c|}
\hline Phytochemical & $\begin{array}{l}\text { Leaves } \\
\text { with Albit }^{\circledR}\end{array}$ & \begin{tabular}{|l|} 
Leaves \\
without \\
Albit $^{\circledR}$
\end{tabular} & $\begin{array}{l}\text { Stem with } \\
\text { Albit }^{\circledR}\end{array}$ & $\begin{array}{l}\text { Stem } \\
\text { without } \text { Albit }^{\circledR}\end{array}$ & $\begin{array}{l}\text { Root with } \\
\text { Albit }^{\circledR}\end{array}$ & $\begin{array}{l}\text { Root without } \\
\text { Albit }^{\circledR}\end{array}$ \\
\hline Saponin & & \multirow{3}{*}{$\begin{array}{l}+ \\
+ \\
+ \\
+\end{array}$} & + & + & - & - \\
\hline Flavonoids & & & - & - & - & - \\
\hline Steroids & & & + & + & + & - \\
\hline Alkaloid & & - & - & - & - & - \\
\hline Tannin & & + & + & + & + & + \\
\hline Glycoside & & . & + & + & + & + \\
\hline Terpenoids & & & - & - & - & - \\
\hline Balsam & & 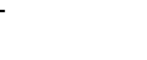 & + & + & + & + \\
\hline
\end{tabular}


Agric. Biol. J. N. Am., 2011, 2(4): 693-697

Table 3: Mineral Composition of Leaves, Stem and Roots of $O$. gratissimum applied with and without Albit ${ }^{\circledR}$

\begin{tabular}{|c|c|c|c|c|c|c|c|}
\hline \multirow[t]{2}{*}{ Treatment } & \multicolumn{7}{|c|}{$m g g^{-1}$} \\
\hline & K & $\mathrm{Mg}$ & $\mathrm{Zn}$ & $\mathrm{Ca}$ & $\mathrm{Fe}$ & $\mathbf{P}$ & Mn \\
\hline Leaf with Albit $^{\circledR}$ & $3.289 a$ & $8.264 b$ & $4.761 a$ & $31.175 a$ & $3.265 b$ & $2.319 a$ & $0.657 a$ \\
\hline Leaf without Albit ${ }^{\circledR}$ & $2.194 b$ & $6.944 \mathrm{c}$ & $2.766 \mathrm{~b}$ & $26.611 b$ & $4.839 a$ & $1.648 \mathrm{bc}$ & $0.721 a$ \\
\hline Stem with Albit ${ }^{\circledR}$ & $2.116 b$ & $6.110 \mathrm{~d}$ & $1.502 \mathrm{c}$ & $23.6553 \mathrm{~cd}$ & $1.309 \mathrm{e}$ & $1.136 \mathrm{~d}$ & $0.440 \mathrm{bc}$ \\
\hline Stem without Albit ${ }^{\circledR}$ & $1.948 \mathrm{~b}$ & $10.948 a$ & $1.132 \mathrm{~d}$ & $25.549 \mathrm{bc}$ & $1.349 \mathrm{e}$ & $1.748 \mathrm{bc}$ & $0.514 \mathrm{~b}$ \\
\hline Root with Albit ${ }^{\circledR}$ & $1.094 \mathrm{c}$ & $7.668 b$ & $2.768 \mathrm{~b}$ & 21.946de & $2.307 \mathrm{c}$ & $1.914 b$ & $0.357 c$ \\
\hline Root without Albit $^{\circledR}$ & $3.108 a$ & $5.236 \mathrm{e}$ & $1.168 \mathrm{~d}$ & $20.676 e$ & $1.809 \mathrm{~d}$ & $1.448 \mathrm{~cd}$ & $0.442 \mathrm{bc}$ \\
\hline
\end{tabular}

Means followed by the same letter(s) within each column are not significant at $5 \%$ significant level, using DMRT.

The Fe content in basil leaf with no $\mathrm{Albit}^{\circledR}$ application was significantly higher $(P \leq 0.05)$ than any other treatments. Meanwhile, the Fe content in the stem of basil applied with or without $\mathrm{Albit}^{\circledR}$ was significantly lower $(P \leq 0.05)$ than other treatments. The highest $P$ content $\left(2.319 \mathrm{mg} \mathrm{g}-{ }^{1}\right)$ was found in the leaf of basil applied with Albit ${ }^{\oplus}$ was significantly higher $(P \leq 0.05)$ than other treatments. There was no significant difference $(P>0.05)$ between the $P$ content in basil leaf without $A \mathrm{lbit}^{\circledR}$ and basil stem without $\mathrm{Albit}^{\circledR}$. The highest Mn content was found in the leaf of basil applied with Albit $\circledast$ and was not significantly different $(P>0.05)$ from the $M n$ content in basil leaf without Albit $^{\circledR}$. There was no significant difference $(P>0.05)$ between the Mn content in basil stem with Albit $₫$ and basil root without $\mathrm{Albit}^{\circledR}$.

The mineral content in the leaf of basil applied with Albit $^{\circledR}$ was in the order of $\mathrm{Ca}>\mathrm{Mg}>\mathrm{Zn}>\mathrm{K}>\mathrm{Fe}>\mathrm{P}>\mathrm{Mn}$ while the mineral content in the basil leaf with no Albit $^{\circledR}$ application was in order of $\mathrm{Ca}>\mathrm{Mg}>\mathrm{Fe}>\mathrm{Zn}>\mathrm{K}>\mathrm{P}>\mathrm{Mn}$. This indicated that $\mathrm{Albit}^{\circledR}$ application altered the concentration of $\mathrm{Zn}$ and $\mathrm{K}$ concentration in the leaf. The mineral content in the basil stem applied with $\mathrm{Albit}^{\circledR}$ was in the order of $\mathrm{Ca}>\mathrm{Mg}>\mathrm{K}>\mathrm{Zn}>\mathrm{Fe}>\mathrm{P}>\mathrm{Mn}$ while the mineral content in the basil stem without Albit applicator was in the order of $\mathrm{Ca}>\mathrm{Mg}>\mathrm{K}>\mathrm{P}>\mathrm{Fe}>\mathrm{Zn}>\mathrm{Mn}$. This indicated that Albit ${ }^{\circledR}$ application alters the concentration of $\mathrm{P}$ and $\mathrm{Zn}$ concentration in the stem. The mineral content in the root of basil applied with $\mathrm{Albit}^{\circledR}$ was in the order of $\mathrm{Ca}>\mathrm{Mg}>\mathrm{Zn}>\mathrm{Fe}>\mathrm{P}>\mathrm{K}>\mathrm{Mn}$ while the mineral content in the basil root without $\mathrm{Albit}^{\circledR}$ application was in order of $\mathrm{Ca}>\mathrm{Mg}>\mathrm{K}>\mathrm{Fe}>\mathrm{P}>\mathrm{Zn}>\mathrm{Mn}$. This also indicated that Albit ${ }^{\circledR}$ application could alter the concentration of $K$ and $\mathrm{Zn}$ concentration in the root.

\section{DISCUSSION}

Unsterilized garden soil was used for raising the $O$. gratissimum in order to simulate natural garden soil. O. gratissimum applied with $\mathrm{Albit}^{\circledR}$ had higher number of leaves, shoot height, leaf area and flower earlier than those without Albit ${ }^{\circledR}$. These results is similar to that of Yakhtanigova (2009) who reported that Albit ${ }^{\circledR}$ application enhanced the productivity of various corn subspecies in Russian agroecology. Enhanced crop productivity by $\mathrm{Albit}^{\circledR}$ might be due to synergism between the plant growth hormone, nutrients and biofungicide it is composed of. This is evident in the result obtained during the foliar application of plant growth regulator (GA3 - 20mgL-1), ) and nutrient solution for improvement of lily flowers (Lilium longifolium) by Mustafa et al. (2009). The mean shoot length of the plants sprayed with both the hormones and nutrients increased by $33 \%$ over the control plants and by $6 \%$ over the other set of plants, which received the treatment of nutrients alone. Number of nodes per stem was also found to increase in the dually treated plants by $71 \%$ and $42 \%$ in that order. The plants receiving dual treatment harbored $92 \%$ greater number of buds per stem over the control plants whereas nutrients- alone treated lily plant showed only $28 \%$ greater number of buds.

The phytochemicals observed in the basil with or without $\mathrm{Albit}^{\circledR}$ in this study was in line with the report of Pessoa et al. (2002) that basil plant contained terpenoid eugenol, saponins; and alkaloids. It was observed that $\mathrm{Albit}^{\circledR}$ application resulted in higher $\mathrm{K}$, $\mathrm{Mg}$ and $\mathrm{Ca}$ yield than those reported by Giami et al., (2005) and El-Adawy and Taha (2001) for basil plant treated with indole butyric acid (IBA). However, the $\mathrm{Fe}, \mathrm{P}$ and $\mathrm{Mn}$ content was similar to those reported 
by the same researchers under the IBA application. It is indicated from this work, that higher content of $\mathrm{K}$, $\mathrm{Mg}$ and $\mathrm{Ca}$ could be induced in basil plant by Albit ${ }^{\mathrm{B}}$ treatment. This might be due to presence of a balanced set of macro and micro elements and terpenes in Albit $^{\circledR}$ biosubstance (Kudrjavcevs et al., 2005; Zlotnikov, 2006).

This study indicated that seed and foliar treatments of basil with $\mathrm{Albit}^{\circledR}$ enhanced the yield and quality of basil through improved growth characteristics and mineral composition. This might be due to the growth promoting and protective potential of the plant by Albit $^{\circledR}$. Thus it proved to be a recommendable input in the cultivation of culinary plants like basil. Further field research work is imperative in order to confirm the efficacy of $\mathrm{Albit}^{\circledR}$ biosubstance on the growth and yield of leafy vegetables on various agroecolological zones in the tropics.

\section{REFERENCES}

Adebolu, T. T and A. O. Salau (2005). Antimicrobial activity of leaf of Ocimum gratissimum on selected diarrhoea causing bacteria in South Western Nigeria. African Journal of Biotechnology, 4(7): 682-684.

Albit Biotechnology LLC (2008). An innovative biopesticide for organic and traditional farming Prospekt Naoka 5, Pushino,Moscow Oblast. 142290. Russia.

AOAC, (1990). Association of Official Analytical Chemist. Official Methods of Analysis, $15^{\text {th }}$ ed. Washington DC.

Chen, M., Theander, T. G., Christensen, S.B., Hviid, L., Zhai L., and A. Kharazmi (1994). Lincochalcone A, a new antimalarial agent and antifungal properties. Preliminary screening of 35 essential oils. J. Sci. Ind. Res. 28: 25-34.

Calixto, J.B. (2000). Efficacy, safety, quality control marketing and regulatory guidelines for herbal medicines (phytotherapeutic agents) Braz. J. Med. Biol. Res.33: 179-189.

Ehiagbonare, J.E.(2004). A Study of the effect of various depth of sowing on seed germination and seedling emergence on Ocimum gratissimum (De wild and Th.Dur) Nig. J. Appl. Sci.22: 195-197.

El-Adawy, T. A. and K.M. Taha (2001). Characteristics and composition of different seed oils and flours. Food Chem., 74:47-54.

El-said, F., Sofowora, E. A., Malcom, S.A. and A. Hofer (2001). An investigation Into the efficacy of Ocimum gratissimum as used in Nigeria native Medicine. Planta medica.17: 195-200

Essawi, T. and M. Srour (2000). Screening of some Palestinian medicinal plants For antibacterial activity. J. Ethnopharmacol.70: 343-349.
George, C. (1994). Development in food science spices; Herb and Edible Fungi $2^{\text {nd }}$ Edition Elsevier publ. Ansterdam London. pp309-327.

Gill, L.S (1992) Ethno medical uses of plants in Nigeria, Uniben press. University of Benin, Edo State, Nig. pp196-177.

Giami, S. Y., S.C. Achinewhu and C. Ibaakee (2005). The quality and sensory attributes of cookies supplemented with basil (Ocimum gratissimum) in J. Food Sci. Technol., 40:613-620.

Kudrjavcev, A., Zaiceva, A., Zlotnikov, A., and K. Zlotnikov (2005). Biopesticide Albit ${ }^{\circledR}$ as a part of flax protection system. Zemledelie, p 34-35.

Mustafa, G. S., Mahmoona, K., and A. Zahoor (2009). Foliar application of plant growth regulator (PGRS) and nutrients for improvement of lily flowers .Pak. J. Bot., 41(1): 233-237

Pessoa, L.M., Morais, S.M., Bevilaqua, C, M.L., and J.H.S. Luciano (2002) Anthelmintic activity of essential oil of Ocimum gratissimum Linn. and eugenol against Haemonchus contortus. Vet. Parasitol. 109: 59-63

Rabelo, M., Souza, E.P., Soares, P.M.G., Miranda, A.V., Matos, F.J.A and D.N Criddle (2003). Antinociceptive properties of the essential oil of Ocimum gratissimum L. (Labiatae) in mice. Brazilian Journal of Medical Research 36: 521-524.

Sahito, A.T.G., Kazi, M.A. Jakhrani, G.H Kazi, G.Q. Shar and M.A. Memon (2002). Elemental investigation of Momordica charantia Linn. and Syziginm jambolana Linn. using atomic absorption spectrophotometer. The Nucleus, 39: 49-54.

SAS - Statistical Analysis System (2002). User's guide. Statistics SAS Institute Inc. Cary N.C., USA.

Sofowora, A. (1993). Medicinal plants and traditional medicine. Spectrum books Ltd. Ibadan, Nigeria. pp. 224-227.

Zlotnikov, A.K (2006). Biopesticide Albit ${ }^{\circledR}$ for increasing yield and protection of agricultures against diseases. Ed. Prof. A. Melkumova. All-Russia Institute of Plant Protection. Russia.

Yakhtanigova, Z. M. (2009). Effect of growth regulators on productivity of various corn subspecies in the Piedmont zone of Kabardino-Bulkaria. Russian Agricultural Sciences. 25:2 84-85. 